\title{
Detection of circulating tumor cells in hepatocellular carcinoma: applications in diagnosis, prognosis prediction and personalized treatment
}

\author{
Peng-Xiang Wang, Jian-Wen Cheng, Xin-Rong Yang \\ Department of Liver Surgery and Transplantation, Liver Cancer Institute, Zhongshan Hospital, Fudan University; Key Laboratory \\ of Carcinogenesis and Cancer Invasion, Ministry of Education, Shanghai 200032, P. R. China.
}

\begin{abstract}
Correspondence to: Dr. Xin-Rong Yang, Department of Liver Surgery and Transplantation, Liver Cancer Institute, Zhongshan Hospital, Fudan University; Key Laboratory of Carcinogenesis and Cancer Invasion, Ministry of Education, 180 Fenglin Road, Shanghai 200032, P. R. China. E-mail: yang.xinrong@zs-hospital.sh.cn
\end{abstract}

How to cite this article: Wang PX, Cheng JW, Yang XR. Detection of circulating tumor cells in hepatocellular carcinoma: applications in diagnosis, prognosis prediction and personalized treatment. Hepatoma Res 2020;6:61. http://dx.doi.org/10.20517/2394-5079.2020.55

Received: 30 May 2020 First Decision: 28 Jun 2020 Revised: 19 Jul 2020 Accepted: 29 Jul 2020 Published: 1 Sep 2020

Academic Editor: Shu-Kui Qin Copy Editor: Cai-Hong Wang Production Editor: Jing Yu

\begin{abstract}
Hepatocellular carcinoma (HCC) is one of the most common malignant tumors worldwide and is associated with poor clinical prognosis, which is mainly caused by tumor recurrence and metastasis. Circulating tumor cells (CTCs) are tumor cells shed into the bloodstream and regarded as the "seeds" of tumor recurrent or metastatic lesions. Over the past decade, the clinical value of CTC analysis has been extensively explored. CTC analysis is a representative form of liquid biopsy, offering a novel solution that can bypass the problems of invasive biopsy procedures, enabling comprehensive, non-invasive, and real-time disease monitoring. In HCC, CTC analysis has facilitated early detection and prognosis prediction, as well as treatment monitoring and therapeutic intervention guiding. In this review, we summarize available literature and provide an overview of CTC biology, detection technologies, and clinical applications in the diagnosis, prognosis prediction, and personalized treatment of HCC.
\end{abstract}

Keywords: Hepatocellular carcinoma, liquid biopsy, circulating tumor cells, biomarkers, personalized medicine

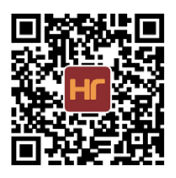




\section{INTRODUCTION}

Hepatocellular carcinoma (HCC) is the sixth most prevalent malignancy worldwide and is currently listed as the fourth leading cause of cancer-related death ${ }^{[1]}$. HCC is a highly aggressive neoplasm; distant organ metastasis can occur at a very early stage ${ }^{[2]}$. Thus, early detection of HCC is of great importance in the management of HCC. Surgical resection or liver transplantation remains the primary therapy for HCC patients. However, only approximately $20 \%-30 \%$ of patients are eligible for surgical intervention at the time of the first diagnosis, most patients have already reached an advanced cancer stage ${ }^{[3]}$. The 5-year survival rate of HCC with Barcelona Clinic Liver Cancer (BCLC) stage 0-A treated with curative therapeutic modalities is $40 \%-70 \%$, but the median overall survival (OS) for patients with BCLC stage B-C is only 11-20 months ${ }^{[4]}$. Even after curative resection, the five-year cumulative recurrence rate is $50 \%-70 \%$, which results in the unsatisfactory long-term outcomes of HCC patients ${ }^{[5,6]}$. Currently, early detection or monitoring HCC recurrence mainly relies on imaging examinations and serum tumor biomarkers such as alpha-fetoprotein (AFP); however, their diagnostic sensitivity is limited and often fails to foresee the tumor metastatic potential ${ }^{[7,8]}$. Therefore, there is an unmet need for reliable biomarkers for early HCC detection and tumor recurrence monitoring.

In recent years, various "liquid biopsy" techniques have emerged and shown significant promise as novel biomarkers for HCC. Liquid biopsy represents a modality of collecting bodily fluids instead of solid tissue for pathophysiological or sequencing analysis. Liquid biopsy offers a solution that can bypass the problems of invasive biopsy procedures, enabling repeated and real-time disease status monitoring ${ }^{[9]}$. Circulating tumor cells (CTCs) and circulating tumor DNA are two of the most widely studied biomarkers in liquid biopsy ${ }^{[10]}$. CTCs are the cells that derive from the primary or metastatic lesions and migrate into circulation and are regarded as the "seeds" of tumor metastasis ${ }^{[11]}$. CTCs represent a unique liquid biopsy form that is different from any of the existing cancer biomarkers, as they are a sampling of the patient's live tumor cells, carrying comprehensive biological information of the primary tumor, including genomic mutations, cancer subtypes, and drug sensitivity ${ }^{[12]}$. CTC research has flourished over the past decade, spanning fields including CTC detection, identification of prognostic significance, and evaluation for treatment response and disease surveillance ${ }^{[13,14]}$.

In the context of HCC, excellent progress has been made using CTCs as blood-based biomarkers ${ }^{[9,14,15]}$. Herein, to gain comprehensive insight into the role of CTCs in HCC, this review article provides an overview of their biology, detection technologies, and clinical significance in HCC.

\section{OVERVIEW OF CTC BIOLOGY}

To date, the definition of CTC from CellSearch ${ }^{\mathrm{TM}}$ system is considered as the current standard: a CTC is an intact nucleated epithelial cell, expressing epithelial cell adhesion molecule (EpCAM) and/or cytokeratin 8,18 , and 19 , and negative for the leukocyte-biomarker $\mathrm{CD} 45^{[16]} . \mathrm{EpCAM}^{+} \mathrm{CTC}$ s were also identified as a stem cell-like subpopulation in HCC, with a highly invasive and metastatic capacity ${ }^{[17]}$.

Thousands of tumor cells are shed into the bloodstream everyday ${ }^{[18]}$; however, most CTCs are eliminated in the bloodstream by shear stress, immune attack, and anoikis ${ }^{[11,19]}$. Only a small number of viable and highly metastatic subpopulations of CTCs could eventually survive and develop into metastatic lesions ${ }^{[20-22]}$. However, the biological mechanism of how CTCs survive the bloodstream and home to distant organs remains largely unknown. CTCs may undergo several adaptations to survive in a hostile environment. A recent study used in vivo genome-wide CRISPR to screen and identify a subset of CTCs with the deregulation of ribosomal protein expression and translation. This CTC subset was significantly associated with enhanced metastatic capabilities and poor clinical outcome ${ }^{[23]}$. Meanwhile, one of the key biological events is epithelial-to-mesenchymal transition (EMT), during which CTCs downregulate epithelial markers such as E-cadherin and gain mesenchymal markers, thus acquiring increased ability to invade the 
adjacent tissues and survive the environmental stress ${ }^{[24-26]}$. Recently, Sun et al. ${ }^{[27]}$ compared EMT-features of CTCs isolated from different vascular sites of HCC patients prior to resection, including peripheral vein, peripheral artery, hepatic veins, infrahepatic inferior vena cava, and portal vein. Single-cell transcriptional characterization demonstrated that CTCs were initially epithelial phenotype at release, but they switched to EMT-activated phenotype during hematogenous transit via Smad2- and b-catenin-related signaling pathways. They suggested such heterogeneous EMT status during the CTC transition may be the result of shear stress in circulation. Nevertheless, while the loss of E-cadherin increased invasion, it also reduced cancer cell proliferation and survival of CTCs in multiple models of breast cancer, indicating the complex phenotypic plasticity of CTCs in EMT status ${ }^{[28,29]}$.

In addition, CTCs may aggregate to form CTC clusters [also referred to as CTC microemboli (CTM)] and travel together in circulation, with or without fibroblasts, leukocytes, endothelial cells, or platelets, which possess significantly higher invasiveness and increased survival ability compared to individual $\mathrm{CTCs}^{[30]}$. Notably, clusters of circulating tumor cells (CTCs) possessed an up to 50 times greater metastatic potential compared with single CTC ${ }^{[31]}$. CTC clusters have been identified in many cancer types including HCC; these clinical studies confirmed that CTC clusters are a much stronger prognostic factor for cancer metastasis than single CTCs ${ }^{[27,32-34]}$. A recent study comprehensively profiled the DNA methylation landscape of single CTCs and CTC clusters from breast cancer patients and mouse models, and the results revealed that binding sites for stemness- and proliferation-associated transcription factors were specifically hypomethylated in CTC clusters, thus promoting the stemness and metastasis of CTC clusters ${ }^{[35]}$. Szczerba et al. ${ }^{[36]}$ identified a specific of CTC-neutrophil cluster in circulation and further confirmed this interaction drove cell cycle progression within the bloodstream and expanded the metastatic potential of CTCs. Targeting this interaction may be rational in treating cancer metastasis. Additionally, the formation of CTC clusters can induce a hypoxic environment that drives hypoxia-inducible factor 1-alpha-mediated mitophagy, clearing damaged mitochondria, and limiting reactive oxygen species. Such a metabolic switch may support the survival and metastatic spread of CTCs in circulation ${ }^{[37]}$. Although the specific mechanism driving CTC cluster formation remains unclear, it is currently considered that CTC clusters arise from oligoclonal tumor cell groupings from the primary tumor or intra-vascular aggregation of single CTCs in circulation ${ }^{[31,38]}$. A recent study has proposed that CTC cluster formation was a dynamic event rather than grouped migration derived from the primary tumor by their multi-vascular sampling, in which CTM displayed an "aggregatedapart-aggregated" pattern during the circulatory pathway. They hypothesized that single CTCs might aggregate spontaneously in blood vessels against the unfavorable microenvironment in the bloodstream ${ }^{[27]}$. Characterization of the mechanism that determines the cluster formation may identify viable therapeutic targets for inhibiting metastasis.

\section{CTC DETECTION TECHNOLOGY}

CTCs are extremely rare and surrounded by numerous blood cells in the bloodstream, thus CTCs are generally required to be firstly enriched from blood samples ${ }^{[39]}$. Reliable CTC enrichment technologies are essential to the downstream comprehensive CTC analysis. Many different technologies have been developed for CTC detection in the past years, and they can be classified into two categories based on whether they make use of the physical or biological properties of the target cells [Table 1] ${ }^{[40]}$. However, most of these technologies for CTC capture and downstream analyses are designed for scientific research, requiring multiple batch-process steps and having relatively limited throughput. The price of CTC analysis is still on the high side (it generally costs hundreds of dollars per patient). A standardized and easy-to-use platform that facilities integrated CTC analysis is still needed.

\section{Immunoaffinity-based method}

The immunoaffinity-based method for CTC detection relies on the tumor-specific antibodies against cell surface markers, including EpCAM, human epidermal growth factor receptor (EGFR)2, prostate-specific 
Table 1. Overview of CTC detection technology

\begin{tabular}{|c|c|c|c|c|c|c|}
\hline Platform & Enrichment method & Phenotypic Markers & Study cohort & $\begin{array}{c}\text { Blood } \\
\text { volume }\end{array}$ & $\begin{array}{c}\text { CTC } \\
\text { positive rate }\end{array}$ & Ref. \\
\hline \multicolumn{7}{|c|}{ Immunoaffinity-based method } \\
\hline $\begin{array}{l}\text { CellSearch } \\
\text { platform }\end{array}$ & Immunomagnetic & ЕрСАМ, CK8/18/19 & $\begin{array}{l}964 \text { metastatic } \\
\text { carcinomas, } 199 \text { NLD, and } \\
145 \mathrm{HD}\end{array}$ & $7.5 \mathrm{~mL}$ & $\begin{array}{l}36.0 \% \\
(\geq 2 \text { CTCs })\end{array}$ & {$[16]$} \\
\hline $\begin{array}{l}\text { Flow cytometric } \\
\text { analysis }\end{array}$ & Immunomagnetic & CD90 & $34 \mathrm{HCC}, 19 \mathrm{LC}$, and $19 \mathrm{HD}$ & $10 \mathrm{~mL}$ & $91.2 \%$ & [44] \\
\hline $\begin{array}{l}\text { Flow cytometric } \\
\text { analysis }\end{array}$ & Flow cytometry & ICAM-1 & $60 \mathrm{HCC}$ & NA & $50.0 \%$ & [46] \\
\hline ASGPR sorting & Immunomagnetic & ASGPR, Hep Par 1 & $\begin{array}{l}85 \mathrm{HCC}, 37 \mathrm{NLD}, 20 \mathrm{HD}, \\
\text { and } 14 \text { patients with other } \\
\text { advanced cancers }\end{array}$ & $5 \mathrm{~mL}$ & $81.0 \%$ & [67] \\
\hline ASGPR sorting & $\begin{array}{l}\text { Density gradient } \\
\text { centrifugation and } \\
\text { Immunomagnetic }\end{array}$ & $\begin{array}{l}\text { ASGPR, pan-cytokeratin, } \\
\text { CPS1 }\end{array}$ & $27 \mathrm{HCC}$ patients & $5 \mathrm{~mL}$ & $89.0 \%$ & [68] \\
\hline $\begin{array}{l}\text { Glypican-3 } \\
\text { sorting }\end{array}$ & $\begin{array}{l}\text { Density gradient } \\
\text { centrifugation and } \\
\text { Immunomagnetic }\end{array}$ & Glypican-3 & $85 \mathrm{HCC}$ patients & $8 \mathrm{~mL}$ & $\begin{array}{l}38.8 \% \\
(\geq 5 \mathrm{CTCs})\end{array}$ & [69] \\
\hline $\begin{array}{l}\text { NanoVelcro CTC } \\
\text { assay }\end{array}$ & Microfluidic device & $\begin{array}{l}\text { ASGPR, glypican-3, } \\
\text { EpCAM, vimentin }\end{array}$ & $61 \mathrm{HCC}, 11 \mathrm{NLD}$, and $8 \mathrm{HD}$ & $4 \mathrm{~mL}$ & $97.0 \%$ & [70] \\
\hline \multicolumn{7}{|c|}{ Biophysical properties-based method } \\
\hline $\begin{array}{l}\text { qRT-PCR-based } \\
\text { platform }\end{array}$ & $\begin{array}{l}\text { Density gradient } \\
\text { centrifugation and Ficoll- } \\
\text { Paque }\end{array}$ & AFP (mRNA) & $44 \mathrm{HCC}$, and $7 \mathrm{HD}$ & $5 \mathrm{~mL}$ & $72.7 \%$ & [39] \\
\hline $\begin{array}{l}\text { qRT-PCR-based } \\
\text { platform }\end{array}$ & $\begin{array}{l}\text { Density gradient } \\
\text { centrifugation and Ficoll- } \\
\text { Paque }\end{array}$ & Cytokeratin 20 (mRNA) & $\begin{array}{l}65 \text { patients with colorectal } \\
\text { cancer }\end{array}$ & $10 \mathrm{~mL}$ & $41.4 \%$ & {$[50]$} \\
\hline $\begin{array}{l}\text { qRT-PCR-based } \\
\text { platform }\end{array}$ & $\begin{array}{l}\text { Density gradient } \\
\text { centrifugation and } \\
\text { OncoQuick }\end{array}$ & Cytokeratin 20 (mRNA) & $\begin{array}{l}37 \text { patients with } \\
\text { gastrointestinal tumors }\end{array}$ & $10 \mathrm{~mL}$ & $30.0 \%$ & {$[51]$} \\
\hline ISET platform & Microfiltration & $\operatorname{AFP}(\mathrm{mRNA})$ & $37 \mathrm{HCC}$ & $15 \mathrm{~mL}$ & $42.9 \%$ & [54] \\
\hline ISET platform & Microfiltration & AFP & $\begin{array}{l}44 \text { patients with primary } \\
\text { liver cancer, } 30 \text { patients } \\
\text { with chronic active } \\
\text { hepatitis, } 39 \text { LC, and } 38 \\
\text { HD }\end{array}$ & $6 \mathrm{~mL}$ & $52.3 \%$ & [55] \\
\hline $\begin{array}{l}\text { ScreenCell } \\
\text { platform }\end{array}$ & Microfiltration & Cytokeratins & NA & NA & NA & {$[56]$} \\
\hline CTC-Chip & Microfluidic device & EpCAM & $\begin{array}{l}116 \text { patients with } \\
\text { metastatic cancer }\end{array}$ & $1 \mathrm{~mL}$ & $99.0 \%$ & [58] \\
\hline HB-Chip & Microfluidic device & EpCAM & $\begin{array}{l}15 \text { patients with } \\
\text { metastatic cancer }\end{array}$ & $1 \mathrm{~mL}$ & $93.0 \%$ & [59] \\
\hline CTC-iChip & Microfluidic device & Cytokeratins & NA & $8 \mathrm{~mL}$ & $97.0 \%$ & {$[60]$} \\
\hline Cluster-Chip & Microfluidic device & Cytokeratins, Ki67 & $\begin{array}{l}27 \text { patients with breast } \\
\text { cancer, } 20 \text { patients with } \\
\text { melanoma, and } 13 \text { patients } \\
\text { with prostate cancer }\end{array}$ & $1 \mathrm{~mL}$ & $30 \%-40 \%$ & {$[61]$} \\
\hline $\begin{array}{l}\text { qRT-PCR-based } \\
\text { platform }\end{array}$ & $\begin{array}{l}\text { Density gradient } \\
\text { centrifugation and } \\
\text { RosetteSep Human CD45 } \\
\text { Depletion Cocktail }\end{array}$ & EpCAM (mRNA) & $299 \mathrm{HCC}$, and $120 \mathrm{HD}$ & $5 \mathrm{~mL}$ & $41.2 \%$ & {$[71]$} \\
\hline $\begin{array}{l}\text { digital PCR-based } \\
\text { platform }\end{array}$ & $\begin{array}{l}\text { Microfluidic device and } \\
\text { immunomagnetic }\end{array}$ & $\begin{array}{l}10 \text { liver-specific } \\
\text { transcripts (mRNA) }\end{array}$ & $16 \mathrm{HCC}$, and $31 \mathrm{NLD}$ & $4 \mathrm{~mL}$ & $56.0 \%$ & {$[72]$} \\
\hline $\begin{array}{l}\text { CanPatrol } \\
\text { platform }\end{array}$ & Microfiltration & $\begin{array}{l}\text { EpCAM, CK8/18/19, } \\
\text { vimentin, twist (mRNA) }\end{array}$ & $33 \mathrm{HCC}$, and $10 \mathrm{HD}$ & $5 \mathrm{~mL}$ & NA & [73] \\
\hline $\begin{array}{l}\text { Labyrinth } \\
\text { microfluidic } \\
\text { device }\end{array}$ & Microfluidic device & $\begin{array}{l}\text { Glypican-3, Glutamine } \\
\text { Synthetase, HepPar-1, } \\
\text { CD44 }\end{array}$ & $42 \mathrm{HCC}$ & $10 \mathrm{~mL}$ & $88.1 \%$ & {$[74]$} \\
\hline
\end{tabular}

CTC: circulating tumor cells; EpCAM: epithelial cell adhesion molecule; CK: cytokeratin; NLD: non-malignant liver disease; HD: healthy donor; HCC: hepatocellular carcinoma; LC: liver cirrhosis; ASGPR: asialoglycoprotein receptor; CPS1: carbamoyl phosphate synthetase 1; QRT-PCR: quantitative reverse transcription polymerase chain reaction; AFP: alpha-fetoprotein 
antigen, and so on ${ }^{[41]}$. EpCAM is the most frequently used antigen in CTC recognition, as the only FDAapproved semi-automated CTC detection device, CellSearch ${ }^{\mathrm{TM}}$ system, is based on the expression of surface EpCAM. CellSearch ${ }^{\mathrm{TM}}$ system utilizes anti-EpCAM-coated magnetic beads for CTC sorting in $7.5 \mathrm{~mL}$ of blood, and the extracted CTCs are then fixed, stained by antibodies against EpCAM and cytokeratin, and counted. EpCAM and cytokeratin also have been regarded as a clinical standard in CTC labeling among other markers ${ }^{[16,42]}$. CellSearch ${ }^{\mathrm{TM}}$ system can retain morphological and immunological characters of isolated cells, thus allowing the following fluorescence-based assays. However, CellSearch ${ }^{\mathrm{TM}}$ system is incompatible with direct downstream single-cell molecular analysis since these cells have been fixed, which limits their clinical utility in CTC-based comprehensive analysis ${ }^{[43]}$. Fluorescence-activated cell sorting is another widely used CTC detecting method that combines conventional flow cytometry technique and immunoaffinity sorting, while this strategy is limited by the makers' selection ${ }^{[4-46]}$.

\section{Biophysical properties-based method}

The biophysical property-based enrichment utilizes various physical properties including density, size, shape, inertia, and electrical property of CTCs to distinguish them from other blood cells ${ }^{[47]}$. These so-called "label-free" methods are gaining increasing attention, as they avoid cell loss when choosing specific antigens targeting CTCs. In addition, unlabeled CTCs are generally compatible with a variety of downstream analyses ${ }^{[48]}$.

Among these strategies, density-based gradient centrifugation is the most commonly used method, which utilizes the differences in specific densities CTCs to separate the target tumor cells and blood cells ${ }^{[49]}$; this is also a common pre-processing step integrated with many methods for CTC detection. Ficoll-Paque ${ }^{\mathrm{TM}}$ is a cell separation medium used for the isolation of CTCs in patients with various types of cancer, including liver cancer and colorectal cancer ${ }^{[39,50]}$. Oncoquick ${ }^{\mathrm{TM}}$ has made improvements in the centrifuge tubes that combines filtration and centrifugation and has superior CTC recovery rate and less blood cell contamination ${ }^{[51]}$. RossetteSep ${ }^{\text {TM }}$ CTC enrichment cocktail is as an example of label-free CTC enrichment, where a mixture of antibodies is used to target and cross-link unwanted blood cells to form immunorosettes, and then density gradient centrifugation is performed to deplete the unwanted cells ${ }^{[52,53]}$.

Another common method that utilizes the biophysical properties of CTC is size-based filtration. The diameter of tumor cells is generally larger than blood cells, and CTCs would be retained in the filter, while smaller blood cells pass through. Isolation by size of epithelial tumor cells (ISET) was developed as a microfilter to isolate tumor cells by a polycarbonate membrane with calibrated pores ${ }^{[54]}$. ISET ${ }^{\mathrm{TM}}$ system can visualize and count CTCs and CTC clusters in blood samples obtained from HCC patients ${ }^{[55]}$. More recently, ScreenCell ${ }^{\mathrm{TM}}$ device was developed as an advanced microfilter to isolate viable CTCs with a high recovery rate. Immunocytochemistry assays for CTCs can be performed directly on the filter ${ }^{[56]}$. To conclude, the filtration method is one of the simplest and most widely studied methods for capturing CTCs. However, this method is limited by its low specificity that the products may be contaminated by other cells owing to natural variation in size of leukocytes, and small CTCs may be lost during the filtration ${ }^{[34]}$.

Alternatively, microfluidic techniques are now increasingly being exploited in CTC isolation, which allows for precise control of fluids in a small volume and rapid sample processing at relatively low cost and high sensitivity ${ }^{[57]}$. Microfluidic platforms enable on-chip CTC isolation, identification, and even culturing. The first microfluidic device named "CTC-chip" was developed to capture rare CTCs in 2007, which successfully identified CTCs in the peripheral blood of patients with metastatic lung, prostate, pancreatic, breast, and colon cancer $^{[58]}$. In 2010, an improved herringbone-chip was developed. The herringboneshaped grooves of this chip can generate a microvortex when blood is pumped, which enhances the contact between the chip surface and tumor cell. Its clinical utility was demonstrated in specimens from patients with prostate cancer ${ }^{[59]}$. Another novel CTC-iChip platform utilizes the distinct differences between cancer 
cells and blood cells in size and deformability, reaching a $97 \%$ yield of rare tumor cells ${ }^{[60]}$. The ClusterChip is a unique $3 \mathrm{D}$ microfiltration system, designed specifically to capture CTC clusters ${ }^{[6]]}$. One obvious advantage of microfluidic chip is that it can isolate CTCs from whole blood in a high-throughput fashion without complicated initial preparation step, thus decreasing the possibility of destruction and loss of $\mathrm{CTCs}^{[62]}$.

\section{Technology developed for detecting CTC in HCC}

CTCs in patients with HCC are a highly heterogeneous population; currently, there are no widely accepted antigens specifically targeting HCC CTCs ${ }^{[27,63]}$. Although CellSearch ${ }^{\mathrm{TM}}$ system is commonly used in CTC detection, it is reported that the EpCAM-based CTC-sorting strategy could only identify approximately $10 \%-35 \%$ of the total amount of tumor cells in blood due to the EMT process and heterogeneous CTC molecular phenotypes ${ }^{[64,65]}$. Thus, a clinically relevant subset of CTCs may be missed by singular epithelial markers-based sorting strategies ${ }^{[2,66]}$. Some research groups have broadened target epitopes to include alternative candidates specific to hepatocytes. For example, Xu et al. ${ }^{[67]}$ developed a novel CTC enumeration system for HCC by taking advantage of a "biotin and anti-biotin antibody" combination, in which circulating HCC cells were bound by biotinylated asialofetuin, an asialoglycoprotein receptor (ASGPR) ligand and subsequently magnetically labeled by anti-biotin antibody-coated magnetic beads, followed by magnetic separation. This system was able to detect CTCs in 69 out of 85 (81\%) HCC patients. The same group used an anti-ASGPR antibody instead of ASGPR ligand with successful CTC detection in $89 \%$ of HCC patients ${ }^{[68]}$. Glypican-3 (GPC3) is an oncofetal heparan sulfate proteoglycan that is currently used as a pathologic biomarker for HCC diagnosis. It can also be used for the detection of HCC-specific CTCs ${ }^{[69]}$. Recently, the novel NanoVelcro CTC assay uses an antibody cocktail targeting the cell-surface markers ASGPR, GPC3, and EpCAM to detect CTCs. It has been showed that multi-marker capture detected greater numbers of CTCs than any individual antibody alone in both cell line and HCC patient samples ${ }^{[70]}$.

"Label-free" strategies have also exhibited great utilities in HCC CTC enrichment. RosetteSep ${ }^{\mathrm{TM}}$ and quantitative reverse transcription-polymerase chain reaction (qRT-PCR) were combined for the optimized CTC detection in HCC patients, yielding a $41.2 \%$ positive rate of $\mathrm{EpCAM}^{\mathrm{mRNA+}} \mathrm{CTCs}^{[71]}$. Kalinich et al. ${ }^{[72]}$ integrated a microfluidic chip device and RNA-based digital PCR to detect molecular signatures derived from HCC CTCs. Using the identified 10 liver-specific transcripts, 9 out of 16 (56\%) untreated HCC cases had detectable CTCs. The CanPatrol ${ }^{\mathrm{TM}} \mathrm{CTC}$ analysis platform used a two-step technique including microfiltration and subsequent RNA in situ hybridization (ISH) assay, to characterize epithelial (EpCAM and cytokeratin 8/9/19) and mesenchymal (Vimentin and Twist) markers of CTCs from patients with HCC $^{[73]}$. Wan et al ${ }^{[74]}$ used a labyrinth microfluidic device to detect CTCs in patients with HCC. They showed that $71.4 \%$ of the HCC patients had CTCs positive for cancer stem cell marker CD44, while 55\% of the patients had the presence of CTM, which was correlated with advanced HCC stage.

\section{EARLY DETECTION AND PREDICTION OF TUMOR PROGRESSION IN HCC}

Research focusing on clinical implications of CTCs in HCC patients has flourished over the past decade. CTCs have shown great potential for the early diagnosis and prognostication of HCC patients ${ }^{[14]}$. The clinical applications of CTC detection in patients with HCC are summarized in Table 2.

Currently, EpCAM ${ }^{+}$CTCs have been extensively investigated in HCC, as immunoaffinity-based CTC enrichment techniques such as CellSearch ${ }^{\mathrm{TM}}$ have been widely used to capture EpCAM ${ }^{+}$CTCs. In 2013, Sun et al ${ }^{[17]}$ used CellSearch ${ }^{\mathrm{TM}}$ to detect $\mathrm{EpCAM}^{+}$CTCs in HCC patients undergoing tumor resection. They found that $66.7 \%$ of HCC patients had detectable EpCAM ${ }^{+}$CTCs preoperatively; moreover, $\mathrm{EpCAM}^{+}$ CTCs $\geq 2$ per $7.5 \mathrm{~mL}$ of blood was the strongest predictor of HCC recurrence. The prognostic value of CTCs was retained in patient subgroups with minor recurrence risk by traditional evaluation. They also found that CTC numbers were significantly correlated to the systemic immune-inflammation index 
Table 2. Applications of CTC detection in HCC

\begin{tabular}{|c|c|c|c|c|c|c|}
\hline Year & $\begin{array}{l}\text { Techniques/ } \\
\text { Platform }\end{array}$ & Model & Objective & Main findings & $\begin{array}{l}\text { Quality of } \\
\text { the evidence } \\
\text { (GRADE) }\end{array}$ & Ref. \\
\hline 2011 & $\begin{array}{l}\text { Flow } \\
\text { cytometric } \\
\text { analysis }\end{array}$ & 82 HCC patients & $\begin{array}{l}\text { Prognostic significance of } \\
\text { stem cell-like CTCs in HCC } \\
\text { undergoing liver resection }\end{array}$ & $\begin{array}{l}\text { Circulating cancer stem cells }>0.01 \% \\
\text { predicted post-hepatectomy HCC } \\
\text { recurrence with high accuracy }\end{array}$ & $\begin{array}{l}\bullet \bullet \circ \circ \\
\text { Low }\end{array}$ & {$[86]$} \\
\hline 2012 & $\begin{array}{l}\text { In vivo flow } \\
\text { cytometry }\end{array}$ & $\begin{array}{l}\text { HCC orthotopic } \\
\text { metastatic tumor } \\
\text { model (mouse) }\end{array}$ & $\begin{array}{l}\text { Monitor CTC dynamics in } \\
\text { vivo }\end{array}$ & $\begin{array}{l}\text { The number of CTCs and early } \\
\text { metastases rates decreased significantly } \\
\text { after the resection of primary tumor }\end{array}$ & $\begin{array}{l}\bullet \circ \circ \circ \\
\text { Very Low }\end{array}$ & [99] \\
\hline 2013 & CellSearch & $123 \mathrm{HCC}$ patients & $\begin{array}{l}\text { Prognostic significance of } \\
\text { CTCs in HCC undergoing } \\
\text { liver resection }\end{array}$ & $\begin{array}{l}\text { A preoperative EpCAM CTCs } \geq 2 / 7.5 \\
\mathrm{~mL} \text { of blood was an independent } \\
\text { prognostic factor for tumor recurrence; } \\
\text { such prognostic value retained in patient } \\
\text { subgroups; a significant decrease of } \\
\text { CTC-positive rates and numbers was } \\
\text { observed } 1 \text { month after resection }\end{array}$ & $\begin{array}{l}\bullet \bullet \bullet \circ \\
\text { Moderate }\end{array}$ & [17] \\
\hline 2013 & CellSearch & 59 HCC patients & $\begin{array}{l}\text { Prognostic significance of } \\
\text { CTCs in HCC undergoing } \\
\text { liver resection }\end{array}$ & $\begin{array}{l}\text { Presence of EpCAM-positive CTC } \\
\text { was associated with intermediate or } \\
\text { advanced HCC stage and worse OS }\end{array}$ & $\begin{array}{l}\bullet \bullet \circ ० \\
\text { Low }\end{array}$ & {$[77]$} \\
\hline 2013 & $\begin{array}{l}\text { Flow } \\
\text { cytometric } \\
\text { analysis }\end{array}$ & $60 \mathrm{HCC}$ patients & $\begin{array}{l}\text { Prognostic significance of } \\
\text { stem cell-like CTCs in HCC } \\
\text { undergoing liver resection }\end{array}$ & $\begin{array}{l}\text { Increased numbers of ICAM-1(+) cells } \\
\text { in blood samples of HCC patients } \\
\text { correlated with worse clinical outcomes }\end{array}$ & $\begin{array}{l}\bullet \bullet \circ ० \\
\text { Low }\end{array}$ & {$[46]$} \\
\hline 2013 & $\begin{array}{l}\text { ASGPR } \\
\text { sorting }\end{array}$ & $60 \mathrm{HCC}$ patients & $\begin{array}{l}\text { Relationship between } \\
\text { the EMT status of CTCs } \\
\text { and HCC metastasis and } \\
\text { prognosis after surgical } \\
\text { resection }\end{array}$ & $\begin{array}{l}\text { Twist and Vimentin expression levels } \\
\text { in CTCs could serve as promising } \\
\text { biomarkers for evaluating metastasis } \\
\text { and prognosis in HCC }\end{array}$ & $\begin{array}{l}\bullet \bullet \circ ० \\
\text { Low }\end{array}$ & [87] \\
\hline 2014 & $\begin{array}{l}\text { qRT-PCR- } \\
\text { based } \\
\text { platform }\end{array}$ & 299 HCC patients & $\begin{array}{l}\text { Diagnostic value of CTC; } \\
\text { Clinical significance of } \\
\text { CTCs in patients treated } \\
\text { with surgical resection, } \\
\text { TACE and radiotherapy }\end{array}$ & $\begin{array}{l}\text { Negative enrichment and qRT-PCR- } \\
\text { based platform can effectively detect } \\
\text { CTCs; the platform might be clinically } \\
\text { useful in auxiliary diagnosis, treatment } \\
\text { response assessment, and early decision } \\
\text { making of antitumor strategies for HCC }\end{array}$ & $\begin{array}{l}\bullet \bullet \bullet \circ \\
\text { Moderate }\end{array}$ & {$[71]$} \\
\hline 2015 & CellSearch & $20 \mathrm{HCC}$ patients & $\begin{array}{l}\text { Prognostic significance of } \\
\text { CTCs and CTC-based DNA } \\
\text { signature }\end{array}$ & $\begin{array}{l}\text { CTC detection was associated with } \\
\text { elevated AFP, vascular invasion, and } \\
\text { poor prognostic factors; sequencing } \\
\text { of CTC DNA identified known HCC } \\
\text { mutations }\end{array}$ & $\begin{array}{l}\bullet \circ \circ ০ \\
\text { Very Low }\end{array}$ & {$[78]$} \\
\hline 2015 & $\begin{array}{l}\text { In vivo flow } \\
\text { cytometry }\end{array}$ & $\begin{array}{l}\text { HCC orthotopic } \\
\text { metastatic tumor } \\
\text { model (mouse) }\end{array}$ & $\begin{array}{l}\text { Monitor CTC dynamics } \\
\text { following sorafenib } \\
\text { treatment in vivo }\end{array}$ & $\begin{array}{l}\text { CTCs can be a biomarker in predicting } \\
\text { disease progression and monitoring } \\
\text { therapeutic efficacy in } \mathrm{HCC}\end{array}$ & $\begin{array}{l}\bullet \circ \circ \circ \\
\text { Very Low }\end{array}$ & [107] \\
\hline 2016 & $\begin{array}{l}\text { qRT-PCR- } \\
\text { based } \\
\text { platform }\end{array}$ & $49 \mathrm{HCC}$ patients & $\begin{array}{l}\text { Prognostic significance } \\
\text { of CTCs and T regulatory } \\
\text { cell in the prediction of } \\
\text { postoperative recurrence }\end{array}$ & $\begin{array}{l}\text { Combination of EpCAM CTC and } \mathrm{T} \\
\text { regulatory/CD } 4(+) \text { cell may be a novel } \\
\text { prognostic predictor for HCC patients }\end{array}$ & $\begin{array}{l}\bullet \circ \circ \circ \\
\text { Very Low }\end{array}$ & {$[83]$} \\
\hline 2016 & $\begin{array}{l}\text { CanPatrol } \\
\text { platform }\end{array}$ & $33 \mathrm{HCC}$ patients & $\begin{array}{l}\text { Diagnostic value of CTCs of } \\
\text { EMT phenotypes in } \mathrm{HCC} \text {; } \\
\text { relationship between the } \\
\text { EMT process of CTCs and } \\
\text { HCC }\end{array}$ & $\begin{array}{l}\text { Epithelial-mesenchymal-mixed CTCs } \\
\text { might be a vital factor for intrahepatic } \\
\text { metastasis, and mesenchymal CTCs } \\
\text { predicated extrahepatic metastasis in } \\
\text { HCC }\end{array}$ & $\begin{array}{l}\bullet \circ 00 \\
\text { Very Low }\end{array}$ & {$[73]$} \\
\hline 2016 & $\begin{array}{l}\text { qRT-PCR- } \\
\text { based } \\
\text { platform }\end{array}$ & 72 HCC patients & $\begin{array}{l}\text { Dynamic monitoring of } \\
\text { CTC counts after surgical } \\
\text { resection }\end{array}$ & $\begin{array}{l}\text { Increased AFP mRNA(+) CTCs can be a } \\
\text { predictor for HCC metastasis before and } \\
\text { after hepatectomy }\end{array}$ & $\begin{array}{l}\bullet \bullet \circ \circ \\
\text { Low }\end{array}$ & {$[101]$} \\
\hline 2016 & $\begin{array}{l}\text { Density } \\
\text { gradient } \\
\text { centrifugation }\end{array}$ & 59 HCC patients & $\begin{array}{l}\text { Determining } \mathrm{pERK} \text { and } \\
\text { pAkt expressions in CTCs } \\
\text { isolated from HCC patients }\end{array}$ & $\begin{array}{l}\text { pERK+/pAkt- CTCs were the } \\
\text { most sensitive to sorafenib and an } \\
\text { independent predictive factor of PFS in } \\
\text { HCC patients treated with sorafenib }\end{array}$ & $\begin{array}{l}\bullet \bullet \circ ० \\
\text { Low }\end{array}$ & [109] \\
\hline 2016 & $\begin{array}{l}\text { Microfluidic } \\
\text { device and } \\
\text { ASGPR } \\
\text { sorting }\end{array}$ & 36 HCC patients & $\begin{array}{l}\text { Isolation of viable CTCs of } \\
\text { HCC for their culture and } \\
\text { drug sensitivity assays }\end{array}$ & $\begin{array}{l}\text { The device can accurately enumerate } \\
\text { CTCs and release viable CTCs for in } \\
\text { vitro culture and further functional } \\
\text { assays }\end{array}$ & $\begin{array}{l}\bullet \circ \circ ০ \\
\text { Very Low }\end{array}$ & [110] \\
\hline 2017 & CellSearch & $61 \mathrm{HCC}$ patients & $\begin{array}{l}\text { Prognostic significance of } \\
\text { CTCs in HCC undergoing } \\
\text { liver resection }\end{array}$ & $\begin{array}{l}\text { Detection of CTC prior to curative- } \\
\text { intended liver resection disclosed an } \\
\text { elevated risk of HCC recurrence }\end{array}$ & $\begin{array}{l}\bullet \bullet \circ \circ \\
\text { Low }\end{array}$ & {$[80]$} \\
\hline 2017 & $\begin{array}{l}\text { CanPatrol } \\
\text { platform }\end{array}$ & 195 HCC patients & $\begin{array}{l}\text { EMT phenotypes of CTCs in } \\
\text { the early diagnosis of HCC } \\
\text { metastasis and progression } \\
\text { after surgical resection }\end{array}$ & $\begin{array}{l}\text { CTCs count and EMT classification } \\
\text { are correlated with clinical stages and } \\
\text { metastasis of HCC }\end{array}$ & $\begin{array}{l}\bullet \bullet \circ ० \\
\text { Low }\end{array}$ & {$[88]$} \\
\hline
\end{tabular}


2018 CellSearch

2018 CellSearch

2018 CellSearch

97 HCC patients

2018 qRT-PCRbased platform

2018 CanPatrol platform

2018 CanPatrol platform

2018 CanPatrol platform

2018 CanPatrol platform

2018 CanPatrol platform

2018 CanPatrol platform

$47 \mathrm{HCC}$ patients (2)

2018 iFISH platform 30 HCC patients

2018 Flow cytometric analysis

2018 Flow

2019 CanPatrol platform

43 patients with liver malignant tumor HCC orthotopic metastatic tumor model (mouse) Spatial heterogeneity of
phenotypic and molecular
characteristics of CTCs

Prognostic significance of CTCs and effect of liver resection on CTCs

Prognostic significance of CTCs in predicting survival outcomes of patients with unresectable HCC treated with TACE

445 HCC patients Clinical value of CTCs with stem-like phenotypes for diagnosis, prognosis, and surveillance in HBV-related HCC

Prognostic significance of EMT phenotypes of CTCs after surgical resection

Relationship between expression of Twist in CTCs and HCC clinical parameters

Prognostic significance of the change of CTC numbers in tumor recurrence and metastasis after surgical resection

Relationship between postoperative circulating tumor cells subtypes and $\mathrm{HCC}$ recurrence

Prognostic significance of EMT phenotypes of CTCs after surgical resection

Prognostic significance of $\mathrm{HCC}$ patients treated with liver transplantation

Prognostic significance treated with liver transplantation

Effect of percutaneous radiofrequency ablation on CTCs

Monitor CTC dynamics following transcatheter arterial embolization cytometry EMT phenotypes of CTCs in of CTCs in HCC patients

Multi-vascular measurement of

CTCs facilitates precise prediction of postoperative relapse or metastasis pattern; profound spatial heterogeneity in cellular distribution and biological features of CTCs during circulation

Both CTC detection incidence and mean CTC counts increased postoperatively; increased postoperative CTC numbers were associated with a worse prognosis

High EpCAM-positive CTC count predicts poor survival of patients with unresectable HCC treated with chemoembolization

CTC panel may be a useful tool in HCC diagnosis, risk prediction, and treatment Moderate response monitoring

Presence of mesenchymal CTCS predicted the shortest relapse-free survival

Twist ${ }^{+}$CTCs were closely correlated with the rate of metastasis or recurrence and the mortality rate in $\mathrm{HCC}$

Unfavorable changes after surgery in CTC counts may be independent prognostic indicators for PFS in patients with HBV-related HCC

HCC patients with positive postoperative peripheral mesenchymal CTCs had a higher risk of early recurrence

CTCs were highly correlated with HCC characteristics, representing a novel marker for early diagnosis and early recurrence prediction

CTC levels and subtypes were not predictive of $\mathrm{HCC}$ recurrence following liver transplantation

iFISH-CTC $\geq 5$ may be a good prognostic indicator for patients with HCC undergoing liver transplantation

Liver tumor ablation might increase the level of mesenchymal phenotype CTCS

EGFR inhibitor application may reduce circulating cancer cells during transcatheter arterial embolization and improve the therapeutic outcomes for advanced HCC

Diagnostic value of different Total CTCs were more effective than EMT phenotypes of CTC in AFP in the diagnosis of HCC; combined $\mathrm{HCC}$ use of total CTCs and AFP can enhance the sensitivity of HCC diagnosis

CTC count and EMT classification were not correlated with clinical stages or predictive of $\mathrm{HCC}$ recurrence

Count of $\triangle C T C$ is predictive of recurrence in patients with early HCC undergoing surgery

$\bullet \bullet \bullet \circ$

Moderate

$\bullet \bullet \circ \circ$

Low

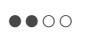

Low

$\bullet \bullet \bullet \circ$

Moderate

$\bullet \bullet \circ \circ$

$\bullet \bullet \circ \circ$

Low

Very Low

$\bullet \bullet \bullet \circ$

Moderate

$\bullet \circ 00$

Very Low

000

Very Low

Very Low

- 0 ○

Very Low

$\bullet \bullet \circ \circ$

Low

$-000$

Very Low

phenotypes after surgical resection association with clinical $\bullet \bullet \circ \circ$

Low
2019 Tapered slit 105 HCC patients Monitor CTC before filter platform outcomes in early-stage $\mathrm{HCC}$ 


\begin{tabular}{|c|c|c|c|c|c|}
\hline 2019 & FISH analysis & 155 HCC patients & $\begin{array}{l}\text { Value of serum dickkopf-1 } \\
\text { and CTCs in predicting the } \\
\text { efficacy and prognosis of } \\
\text { TACE treatment in HCC }\end{array}$ & $\begin{array}{l}\text { CTCs levels can predict the efficacy and } \\
\text { prognosis of TACE treatment in patients } \\
\text { with HCC }\end{array}$ & $\begin{array}{l}\bullet \circ \circ \circ \\
\text { Very Low }\end{array}$ \\
\hline 2020 & $\begin{array}{l}\text { CanPatrol } \\
\text { platform }\end{array}$ & 136 HCC patients & $\begin{array}{l}\text { Relationship between CTC } \\
\text { status and outcomes of } \\
\text { different surgical methods } \\
\text { in HCC }\end{array}$ & $\begin{array}{l}\text { Anatomic resection might improve } \\
\text { the survival of HCC patients, but } \\
\text { only those with low CTC count and } \\
\text { negative mesenchymal and epithelial/ } \\
\text { mesenchymal-CTC phenotypes }\end{array}$ & $\begin{array}{l}\bullet \bullet \circ \circ \\
\text { Low }\end{array}$ \\
\hline 2020 & $\begin{array}{l}\text { PowerMag } \\
\text { negative } \\
\text { selection } \\
\text { system }\end{array}$ & $30 \mathrm{HCC}$ patients & $\begin{array}{l}\text { Longitudinal monitoring } \\
\text { the treatment response } \\
\text { of patients with locally } \\
\text { advanced HCC using CTCs }\end{array}$ & $\begin{array}{l}\text { Sequential CTC enumeration during } \\
\text { treatment can benefit the management } \\
\text { of patients with locally advanced or } \\
\text { metastatic HCC, in particular for the } \\
\text { AFP-low cases }\end{array}$ & $\begin{array}{l}\bullet \circ \circ \circ \\
\text { Very Low }\end{array}$ \\
\hline
\end{tabular}

CTC: circulating tumor cells; HCC: hepatocellular carcinoma; EpCAM: epithelial cell adhesion molecule; OS: overall survival; ICAM1: intercellular cell adhesion molecule-1; EMT: epithelial-to-mesenchymal transition; ASGPR: asialoglycoprotein receptor; TACE: transcatheter arterial chemoembolization; GRT-PCR: quantitative reverse transcription polymerase chain reaction; AFP: alphafetoprotein; pERK: phosphorylated ERK; pAkt: phosphorylated Akt; PFS: progression-free survival; HBV: hepatitis B virus; FISH: fluorescence in situ hybridization; EGFR: epidermal growth factor receptor

(SII), a novel index based on peripheral lymphocyte, neutrophil, and platelet counts. HCC patients who experienced unfavorable internal inflammatory alterations after radical hepatic resection suffered an earlier recurrence and distant metastasis. Thus, they proposed that the dissemination and colonization of CTCs may be influenced by host inflammatory and immune response status ${ }^{[75,76]}$. In 2018 , Sun et al. ${ }^{[27]}$ showed that CTC and circulating tumor cluster burden in hepatic veins and peripheral circulation prognosticated postoperative lung metastasis and intrahepatic recurrence in HCC patients by multi-vascular sites sampling, respectively. This study provided new insight that multi-vascular measurement of CTCs could facilitate precise prediction of postoperative relapse or metastasis patterns in HCC. Other studies using CellSearch $^{\mathrm{TM}}$ also demonstrated that patients who had $\mathrm{EpCAM}^{+}$CTCs were associated with vascular invasion ${ }^{[77,78]}$, significantly elevated $\mathrm{AFP}^{[78]}$, more advanced BCLC stage ${ }^{[77]}$, higher recurrence rate ${ }^{[79,80]}$, and shorter OS $^{[77,79]}$. High EpCAM-positive CTC count also predicted poor survival of patients with unresectable HCC treated with transcatheter arterial chemoembolization (TACE) ${ }^{[81]}$.

PCR-based methods can detect tumor-specific mRNA in blood cells with high sensitivity and specificity. Yao et al ${ }^{[82]}$ reported the combination of positive/negative cell sorting methods and RT-PCR could effectively detect AFP mRNA-positive CTCs in HCC patients. Guo et al. ${ }^{[71]}$ established an optimized platform based on negative enrichment and qRT-PCR for the detection of EpCAM mRNA-positive CTCs in HCC. Using their platform, they reported good sensitivity and specificity of PCR-based CTC detection in a cohort of 299 HCC patients. The novel platform exhibited $76.6 \%$ consistency with the CellSearch $^{\mathrm{TM}}$ system while required a reduced blood volume $(5 \mathrm{~mL})$. They also reported that low pretreatment CTC levels were significantly correlated to a better prognosis after curative resection, TACE, or radiotherapy for patients with HCC. Using the same platform, Zhou et al. ${ }^{[83]}$ discovered that patients with high CTC/Treg levels exhibited higher recurrence rates than those with low CTC/Treg counterparts (66.7\% vs. 10.3\%, $P<$ 0.001 ) by combining the measurement of $\mathrm{EpCAM}^{\mathrm{mRNA}+} \mathrm{CTCs}$ and $\mathrm{CD} 4^{+} \mathrm{CD} 25^{+} \mathrm{Foxp}^{+}$Treg cells. Currently, AFP examination remains the most extensively used screening method to indicate early HCC. However, about $30 \%-40 \%$ of HCC patients are AFP negative and the specificity of AFP may be flawed by false-positive results ${ }^{[8,85]}$. CTC enumeration can be useful in the early detection of HCC since tumor dissemination can occur at the early stage of tumor development ${ }^{[2]}$. In 2018, the same group developed a qRT-PCR-based multimarker (EpCAM, CD90, CD133, and CK19) diagnostic CTC panel for the identification of CTCs with stem-like phenotypes. They obtained a sensitivity of over $70.0 \%$ and specificity of over $90.0 \%$ in a well-designed multicenter cohort $(n=1,006)$. This panel performed equally well in detecting early-stage and AFP-negative HCC as in differentiating HCC from patients with benign liver diseases. The CTC panel outperformed AFP as a biomarker in terms of differential diagnostic capability, yielding higher area under 
curve (AUC) value than AFP alone. This study demonstrated the clinical significance of using CTC panel in diagnosis and real-time risk evaluation for $\mathrm{HCC}^{[63]}$.

Increasing efforts have been made to investigate the correlation between different molecular phenotypes of CTCs and corresponding clinical outcomes. The stem-like phenotype of CTC has been explored as a strong predictor of the clinical outcome of patients with HCC. For instance, circulating CD 45 intercellular cell adhesion molecule-1 (+) (ICAM-1 ${ }^{+}$) cells were regarded as HCC CTCs with stem cell-like properties. Liu et al ${ }^{[46]}$ showed that patients with a higher burden of ICAM-1 ${ }^{+}$CTCs had significantly shorter diseasefree survival and OS. Fan et al. ${ }^{[86]}$ also reported that circulating cancer stem cells $\left(\mathrm{CD} 45^{-} \mathrm{CD} 90^{+} \mathrm{CD} 44^{+}\right.$) predicted post-hepatectomy HCC recurrence with high accuracy. Moreover, EMT subtypes of CTCs have been studied for the correlation to clinicopathological features and prognosis of HCC patients. It is reported that a presence or dominance of mesenchymal-like CTCs represented worse clinical outcomes for HCC patients due to earlier tumor relapse and metastasis ${ }^{[73,87]}$. The majority of these studies used the CanPatrol ${ }^{\mathrm{TM}}$ platform for CTC analysis ${ }^{[7388-94]}$. In a cohort of 113 HCC patients (65\% BCLC 0/A) and 57 non-malignant liver diseases patients, the system presented a higher diagnostic value $(\mathrm{AUC}=0.774,95 \% \mathrm{CI}$ : 0.704-0.834) of HCC than AFP [0.669 (AUC $=0.669,95 \% \mathrm{CI}: 0.587-0.750)]$. A further combination of CTCs and AFP showed the highest diagnostic capability $(\mathrm{AUC}=0.821,95 \% \mathrm{CI}: 0.756-0.886)^{[92]}$. The proportion of mixed EMT status CTCs or mesenchymal CTCs was associated with advanced BCLC stages, higher metastatic tendency, and elevated serum levels of $\mathrm{AFP}^{[88,89]}$. Yin et al ${ }^{[90]}$ reported that twist expression in CTCs could serve as a biomarker for evaluating HCC metastasis and prognosis. Similarly, Wang et al ${ }^{[93]}$ studied 62 HCC patients undergoing surgical resection and found that mesenchymal CTC positivity was an independent risk factor for early recurrence. A similar study using $\mathrm{CanPatrol}^{\mathrm{TM}}$ platform also found that CTCs undergoing EMT were significantly associated with early recurrence, multi-intrahepatic recurrence, and lung metastasis ${ }^{[94]}$. However, a recent study reported that CTCs undergoing EMT were poorly correlated with clinical stages or predictive of recurrence of HCC using the platform ${ }^{[95]}$. Another study using this platform also failed to uncover significant associations between change in total CTCs or CTC subtypes and HCC recurrence in a cohort consisting of 47 patients who underwent liver transplantation ${ }^{[96]}$. Nevertheless, Xue et al. ${ }^{[97]}$ utilized an iFISH ${ }^{\circ}$ platform to detect CTCs in patients undergoing liver transplantation and found that patients with preoperative iFISH-CTCs $\geq 5$ in $7.5 \mathrm{~mL}$ of blood had significantly shorter recurrence-free survival than those with lower CTCs. Further large, multicenter studies are still needed to confirm the association between different molecular phenotypes of CTCs and HCC prognosis.

\section{TUMOR MONITORING AND GUIDING PERSONALIZED THERAPEUTIC INTERVENTION IN HCC}

Surgical resection remains the most effective therapy for HCC. CTCs could serve as a complementary tool to assess the efficacy of surgical resection and monitor tumor progression ${ }^{[8,14]}$. Qi et al.$^{[98]}$ recently compared the outcomes of patients undergoing anatomical or non-anatomical resection according to the number and EMT phenotype of CTCs. They suggested that anatomic resection may improve the survival of HCC patients, for those with low CTC count, negative epithelial/mesenchymal hybrid CTCs, and mesenchymal CTCs. Thus, CTC analysis before surgery can be used to better guide the resection method for HCC. Meanwhile, the decrease of CTC count after surgical treatment often reflects therapeutic efficacy. Fan et al. ${ }^{[99]}$ investigated the effect of liver tumor resection on CTC dynamics using in vivo flow cytometry (IVFC) in a green fluorescent protein-transfected HCC orthotopic metastatic mouse model. Their preliminary study found that the number of CTCs and early metastases rates decreased significantly after the resection of the primary tumor. Several clinical studies obtained similar results that CTC load decreased significantly after tumor resection, while increased CTC numbers after surgery were associated with a worse prognosis in patients with $\mathrm{HCC}^{[17,63,71,79,100]}$. Besides, Jin et al. ${ }^{[101]}$ explored the clinical value of serial postsurgical observation (at $0,3,6,9$, and 12 months) of AFP mRNA level of CTCs in assessing the therapeutic effectiveness of hepatectomy. 
In addition, the dynamic change of CTC counts reflected the treatment response in patients treated with locoregional therapies, including TACE, radiotherapy, and radiofrequency ablation ${ }^{[3,71,102,103]}$. Li et al ${ }^{[103]}$ found that the total number of CTCs and mesenchymal phenotype CTCs significantly increased three days after percutaneous radiofrequency ablation of liver tumor. However, no significant correlation was identified between changes in CTC levels and all the radiofrequency ablation factors. Recently, Rau et al. ${ }^{[104]}$ demonstrated the clinical utilities of sequential CTC monitoring in a patient cohort $(n=17)$ with locally advanced or metastatic HCC accepted systemic/targeted therapy. They found that a change in the CTC count correlated with the patient treatment response in most of the cases and was particularly useful for monitoring patients without elevated serum AFP levels.

Drug therapy is an important component of the comprehensive treatment of HCC. However, only a few patients are sensitive to chemotherapy drugs. Compared with other liquid biopsy biomarkers, CTCs contain more information on the functional characteristics and biological behaviors of tumor ${ }^{[105,106]}$. Thus, CTCs can be a more relevant biomarker in guiding personalized therapeutic intervention for cancer patients. Yan et al. ${ }^{[107]}$ monitored the effect of sorafenib on CTC count in an orthotopic HCC mouse model by IVFC. They showed that the sorafenib treatment could dramatically reduce the number of CTCs, associated with a decreased probability of lung metastasis. Zhu et al. ${ }^{[108]}$. showed that the application of EGFR inhibitor could reduce CTC numbers caused as a side effect of transcatheter arterial embolization. Moreover, Li et al. ${ }^{[109]}$ presented a novel system to simultaneously detect the expressions of the phosphorylated extracellular signal-regulated kinase (pERK) and phosphorylated protein kinase B (pAkt) in CTCs. They showed that CTCs can be used in place of tumor tissue for characterization of pERK/pAkt expression, and HCC patients with pERK+/ pAkt- CTCs were more sensitive to sorafenib treatment. Another potential application of CTCs in drug therapy is to test the drug sensitivity by CTC culture. Zhang et al. ${ }^{[110]}$ used a microfluidic chip to isolate and release viable CTCs and then performed chemotherapeutic drug assay. The number of spheroids formed by CTCs declined greatly when cultured with sorafenib or oxaliplatin. Furthermore, the novel single-cell sequencing technology makes individual CTC profiling possible, which may provide more valuable drug target information and guide individualized treatment in the future clinical practice ${ }^{[12,111,112]}$.

\section{CONCLUSION}

CTC analysis is an exciting field that is gaining increasing attention thanks to the significant technological advancements in CTC isolation and detection. As an important component of "liquid biopsy", CTC analysis enables early cancer detection, prognosis prediction, therapy response monitoring, and novel therapeutic target identification in patients with HCC. However, significant challenges still exist in translating CTC analysis from bench to bedside. Most of the current studies in HCC used different technologies or platforms to detect CTCs in a relatively small, single-centered cohort with widely varying patient demographics, making it difficult to compare studies. Therefore, clinical utilities of CTC should be validated in more multicenter, large, and long-term studies using a standardized CTC assay. Moreover, CTCs hold great promise as a tool to deepen our knowledge of the complicated metastasis process. In recent years, CTCs researches have moved beyond simple CTC enumeration towards more sophisticated molecular analyses. Single-cell sequencing technology may pave the way for using CTCs to understand the underlying mechanisms of cancer metastasis and provide critical insights for new therapeutic strategies. Hopefully, routine CTCs evaluation will become a clinical reality in the near future.

\section{DECLARATIONS}

\section{Authors' contributions}

Manuscript writing, design, planning: Wang PX, Cheng JW, Yang XR

Manuscript review and editing: Yang XR

Approved the final manuscript: Wang PX, Cheng JW, Yang XR 


\section{Availability of data and materials}

Not applicable.

\section{Financial support and sponsorship}

This study was supported by grants from the National Key Research and Development Program (2016YFF0101405 and 2016YFC0902400), the State Key Program of National Natural Science of China (81530077 and 81830102), the National Natural Science Foundation of China (81602543, 81672839, 81572823, 81772578, 81772551, and 81872355), the Strategic Priority Research Program of the Chinese Academy of Sciences (XDA12020105 and XDA12020103), the Shanghai Municipal Health Commission Collaborative Innovation Cluster Project (2019CXJQ02), Projects from the Shanghai Science and Technology Commission (19441905000) and Projects from Shanghai Municipal Key Clinical Specialty.

\section{Conflicts of interest}

All authors declared that there are no conflicts of interest.

\section{Ethical approval and consent to participate}

Not applicable.

\section{Consent for publication}

Not applicable.

\section{Copyright}

(c) The Author(s) 2020.

\section{REFERENCES}

1. Siegel RL, Miller KD, Jemal A. Cancer statistics, 2020. CA Cancer J Clin 2020;70:7-30.

2. Klein CA. Parallel progression of primary tumours and metastases. Nat Rev Cancer 2009;9:302-12.

3. European Association for the Study of the Liver. Electronic address eee, European Association for the Study of the L. EASL Clinical Practice Guidelines: management of hepatocellular carcinoma. J Hepatol 2018;69:182-236.

4. Villanueva A, Hernandez-Gea V, Llovet JM. Medical therapies for hepatocellular carcinoma: a critical view of the evidence. Nat Rev Gastroenterol Hepatol 2013;10:34-42.

5. Tabrizian P, Jibara G, Shrager B, Schwartz M, Roayaie S. Recurrence of hepatocellular cancer after resection: patterns, treatments, and prognosis. Ann Surg 2015;261:947-55.

6. Heimbach JK, Kulik LM, Finn RS, Sirlin CB, Abecassis MM, et al. AASLD guidelines for the treatment of hepatocellular carcinoma. Hepatology 2018;67:358-80.

7. Agopian VG, Harlander-Locke MP, Markovic D, Zarrinpar A, Kaldas FM, et al. Evaluation of Patients With Hepatocellular Carcinomas That Do Not Produce alpha-Fetoprotein. JAMA Surg 2017;152:55-64.

8. Chen VL, Xu D, Wicha MS, Lok AS, Parikh ND. Utility of liquid biopsy analysis in detection of hepatocellular carcinoma, determination of prognosis, and disease monitoring: a systematic review. Clin Gastroenterol Hepatol 2020; doi: 10.1016/j.cgh.2020.04.019.

9. Mann J, Reeves HL, Feldstein AE. Liquid biopsy for liver diseases. Gut 2018;67:2204-12.

10. Diaz LA Jr, Bardelli A. Liquid biopsies: genotyping circulating tumor DNA. J Clin Oncol 2014;32:579-86.

11. Massague J, Obenauf AC. Metastatic colonization by circulating tumour cells. Nature 2016;529:298-306.

12. Keller L, Pantel K. Unravelling tumour heterogeneity by single-cell profiling of circulating tumour cells. Nat Rev Cancer 2019;19:553-67.

13. de Bono JS, Scher HI, Montgomery RB, Parker C, Miller MC, et al. Circulating tumor cells predict survival benefit from treatment in metastatic castration-resistant prostate cancer. Clin Cancer Res 2008;14:6302-9.

14. Ahn JC, Teng PC, Chen PJ, Posadas E, Tseng HR, et al. Detection of circulating tumor cells and their implications as a novel biomarker for diagnosis, prognostication, and therapeutic monitoring in hepatocellular carcinoma. Hepatology 2020; doi: 10.1002/hep.31165.

15. Ye Q, Ling S, Zheng S, Xu X. Liquid biopsy in hepatocellular carcinoma: circulating tumor cells and circulating tumor DNA. Mol Cancer 2019;18:114.

16. Allard WJ, Matera J, Miller MC, Repollet M, Connelly MC, et al. Tumor cells circulate in the peripheral blood of all major carcinomas but not in healthy subjects or patients with nonmalignant diseases. Clin Cancer Res 2004;10:6897-904.

17. Sun YF, Xu Y, Yang XR, Guo W, Zhang X, et al. Circulating stem cell-like epithelial cell adhesion molecule-positive tumor cells indicate poor prognosis of hepatocellular carcinoma after curative resection. Hepatology 2013;57:1458-68.

18. Chang YS, di Tomaso E, McDonald DM, Jones R, Jain RK, et al. Mosaic blood vessels in tumors: frequency of cancer cells in contact 
with flowing blood. Proc Natl Acad Sci U S A 2000;97:14608-13.

19. Mohme M, Riethdorf S, Pantel K. Circulating and disseminated tumour cells - mechanisms of immune surveillance and escape. Nat Rev Clin Oncol 2017;14:155-67.

20. Liberko M, Kolostova K, Bobek V. Essentials of circulating tumor cells for clinical research and practice. Crit Rev Oncol Hematol 2013;88:338-56.

21. Kim MY, Oskarsson T, Acharyya S, Nguyen DX, Zhang XH, et al. Tumor self-seeding by circulating cancer cells. Cell 2009;139:1315-26.

22. Coumans FA, Siesling S, Terstappen LW. Detection of cancer before distant metastasis. BMC Cancer 2013;13:1-12.

23. Ebright RY, Lee S, Wittner BS, Niederhoffer KL, Nicholson BT, et al. Deregulation of ribosomal protein expression and translation promotes breast cancer metastasis. Science 2020;367:1468-73.

24. Mani SA, Guo W, Liao MJ, Eaton EN, Ayyanan A, et al. The epithelial-mesenchymal transition generates cells with properties of stem cells. Cell 2008;133:704-15.

25. Kalluri R. EMT: when epithelial cells decide to become mesenchymal-like cells. J Clin Invest 2009;119:1417-9.

26. Yu M, Bardia A, Wittner BS, Stott SL, Smas ME, et al. Circulating breast tumor cells exhibit dynamic changes in epithelial and mesenchymal composition. Science 2013;339:580-4.

27. Sun YF, Guo W, Xu Y, Shi YH, Gong ZJ, et al. Circulating tumor cells from different vascular sites exhibit spatial heterogeneity in epithelial and mesenchymal composition and distinct clinical significance in hepatocellular carcinoma. Clin Cancer Res 2018;24:547-59.

28. Padmanaban V, Krol I, Suhail Y, Szczerba BM, Aceto N, et al. E-cadherin is required for metastasis in multiple models of breast cancer. Nature 2019;573:439-44.

29. Thompson EW, Haviv I. The social aspects of EMT-MET plasticity. Nat Med 2011;17:1048-9.

30. Aceto N. Bring along your friends: homotypic and heterotypic circulating tumor cell clustering to accelerate metastasis. Biomed J 2020;43:18-23.

31. Aceto N, Bardia A, Miyamoto DT, Donaldson MC, Wittner BS, et al. Circulating tumor cell clusters are oligoclonal precursors of breast cancer metastasis. Cell 2014;158:1110-22.

32. Manjunath Y, Upparahalli SV, Suvilesh KN, Avella DM, Kimchi ET, et al. Circulating tumor cell clusters are a potential biomarker for detection of non-small cell lung cancer. Lung Cancer 2019;134:147-50.

33. Wang C, Mu Z, Chervoneva I, Austin L, Ye Z, et al. Longitudinally collected CTCs and CTC-clusters and clinical outcomes of metastatic breast cancer. Breast Cancer Res Treat 2017;161:83-94.

34. Wang L, Li Y, Xu J, Zhang A, Wang X, et al. Quantified postsurgical small cell size CTCs and EpCAM(+) circulating tumor stem cells with cytogenetic abnormalities in hepatocellular carcinoma patients determine cancer relapse. Cancer Lett 2018;412:99-107.

35. Gkountela S, Castro-Giner F, Szczerba BM, Vetter M, Landin J, et al. Circulating tumor cell clustering shapes DNA methylation to enable metastasis seeding. Cell 2019;176:98-112.e14.

36. Szczerba BM, Castro-Giner F, Vetter M, Krol I, Gkountela S, et al. Neutrophils escort circulating tumour cells to enable cell cycle progression. Nature 2019;566:553-7.

37. Labuschagne CF, Cheung EC, Blagih J, Domart MC, Vousden KH. Cell clustering promotes a metabolic switch that supports metastatic colonization. Cell Metab 2019;30:720-34.e5.

38. Liu X, Taftaf R, Kawaguchi M, Chang YF, Chen W, et al. Homophilic CD44 interactions mediate tumor cell aggregation and polyclonal metastasis in patient-derived breast cancer models. Cancer Discov 2019;9:96-113.

39. Guo J, Yao F, Lou Y, Xu C, Xiao B, et al. Detecting carcinoma cells in peripheral blood of patients with hepatocellular carcinoma by immunomagnetic beads and rt-PCR. J Clin Gastroenterol 2007;41:783-8.

40. Shen Z, Wu A, Chen X. Current detection technologies for circulating tumor cells. Chem Soc Rev 2017;46:2038-56.

41. Joosse SA, Gorges TM, Pantel K. Biology, detection, and clinical implications of circulating tumor cells. EMBO Mol Med 2015;7:1-11.

42. Deng G, Herrler M, Burgess D, Manna E, Krag D, et al. Enrichment with anti-cytokeratin alone or combined with anti-EpCAM antibodies significantly increases the sensitivity for circulating tumor cell detection in metastatic breast cancer patients. Breast Cancer Res 2008;10:R69.

43. Andree KC, van Dalum G, Terstappen LW. Challenges in circulating tumor cell detection by the CellSearch system. Mol Oncol 2016;10:395-407.

44. Yu D, Sun X, Qiu Y, Zhou J, Wu Y, et al. Identification and clinical significance of mobilized endothelial progenitor cells in tumor vasculogenesis of hepatocellular carcinoma. Clin Cancer Res 2007;13:3814-24.

45. Yang ZF, Ngai P, Ho DW, Yu WC, Ng MN, et al. Identification of local and circulating cancer stem cells in human liver cancer. Hepatology 2008;47:919-28.

46. Liu S, Li N, Yu X, Xiao X, Cheng K, et al. Expression of intercellular adhesion molecule 1 by hepatocellular carcinoma stem cells and circulating tumor cells. Gastroenterology 2013;144:1031-41.e10.

47. Harouaka RA, Nisic M, Zheng SY. Circulating tumor cell enrichment based on physical properties. J Lab Autom 2013;18:455-68.

48. Song Y, Tian T, Shi Y, Liu W, Zou Y, et al. Enrichment and single-cell analysis of circulating tumor cells. Chem Sci 2017;8:1736-51.

49. Gertler R, Rosenberg R, Fuehrer K, Dahm M, Nekarda H, et al. Detection of circulating tumor cells in blood using an optimized density gradient centrifugation. 2003;162:149.

50. Weitz J, Kienle P, Lacroix J, Willeke F, Benner A, et al. Dissemination of tumor cells in patients undergoing surgery for colorectal cancer. Clin Cancer Res 1998;4:343-8.

51. Rosenberg R, Gertler R, Friederichs J, Fuehrer K, Dahm M, et al. Comparison of two density gradient centrifugation systems for the enrichment of disseminated tumor cells in blood. Cytometry 2002;49:150-8. 
52. Zuccolo J, Unruh TL, Deans JP. Efficient isolation of highly purified tonsil B lymphocytes using RosetteSep with allogeneic human red blood cells. BMC Immunol 2009;10:30.

53. Hayes GM, Busch R, Voogt J, Siah IM, Gee TA, et al. Isolation of malignant B cells from patients with chronic lymphocytic leukemia (CLL) for analysis of cell proliferation: validation of a simplified method suitable for multi-center clinical studies. Leuk Res 2010;34:809-15.

54. Vona G, Sabile A, Louha M, Sitruk V, Romana S, et al. Isolation by size of epithelial tumor cells: a new method for the immunomorphological and molecular characterization of circulatingtumor cells. Am J Pathol 2000;156:57-63.

55. Vona G, Estepa L, Beroud C, Damotte D, Capron F, et al. Impact of cytomorphological detection of circulating tumor cells in patients with liver cancer. Hepatology 2004;39:792-7.

56. Desitter I, Guerrouahen BS, Benali-Furet N, Wechsler J, Janne PA, et al. A new device for rapid isolation by size and characterization of rare circulating tumor cells. Anticancer Res 2011;31:427-41.

57. Dong Y, Skelley AM, Merdek KD, Sprott KM, Jiang C, et al. Microfluidics and circulating tumor cells. J Mol Diagn 2013;15:149-57.

58. Nagrath S, Sequist LV, Maheswaran S, Bell DW, Irimia D, et al. Isolation of rare circulating tumour cells in cancer patients by microchip technology. Nature 2007;450:1235-9.

59. Stott SL, Hsu CH, Tsukrov DI, Yu M, Miyamoto DT, et al. Isolation of circulating tumor cells using a microvortex-generating herringbone-chip. Proc Natl Acad Sci U S A 2010;107:18392-7.

60. Karabacak NM, Spuhler PS, Fachin F, Lim EJ, Pai V, et al. Microfluidic, marker-free isolation of circulating tumor cells from blood samples. Nat Protoc 2014;9:694-710.

61. Sarioglu AF, Aceto N, Kojic N, Donaldson MC, Zeinali M, et al. A microfluidic device for label-free, physical capture of circulating tumor cell clusters. Nat Methods 2015;12:685-91.

62. Qian W, Zhang Y, Chen W. Capturing cancer: emerging microfluidic technologies for the capture and characterization of circulating tumor cells. Small 2015;11:3850-72.

63. Guo W, Sun YF, Shen MN, Ma XL, Wu J, et al. Circulating tumor cells with stem-like phenotypes for diagnosis, prognosis, and therapeutic response evaluation in hepatocellular carcinoma. Clin Cancer Res 2018;24:2203-13.

64. de Boer CJ, van Krieken JH, Janssen-van Rhijn CM, Litvinov SV. Expression of Ep-CAM in normal, regenerating, metaplastic, and neoplastic liver. J Pathol 1999;188:201-6.

65. Yamashita T, Forgues M, Wang W, Kim JW, Ye Q, et al. EpCAM and alpha-fetoprotein expression defines novel prognostic subtypes of hepatocellular carcinoma. Cancer Res 2008;68:1451-61.

66. Nicolazzo C, Gradilone A, Loreni F, Raimondi C, Gazzaniga P. EpCAM(low) circulating tumor cells: gold in the waste. Dis Markers 2019;2019:1718920.

67. Xu W, Cao L, Chen L, Li J, Zhang XF, et al. Isolation of circulating tumor cells in patients with hepatocellular carcinoma using a novel cell separation strategy. Clin Cancer Res 2011;17:3783-93.

68. Li J, Chen L, Zhang X, Zhang Y, Liu H, et al. Detection of circulating tumor cells in hepatocellular carcinoma using antibodies against asialoglycoprotein receptor, carbamoyl phosphate synthetase 1 and pan-cytokeratin. PLoS One 2014;9:e96185.

69. Hamaoka M, Kobayashi T, Tanaka Y, Mashima H, Ohdan H. Clinical significance of glypican-3-positive circulating tumor cells of hepatocellular carcinoma patients: a prospective study. PLoS One 2019;14:e0217586.

70. Court CM, Hou S, Winograd P, Segel NH, Li QW, et al. A novel multimarker assay for the phenotypic profiling of circulating tumor cells in hepatocellular carcinoma. Liver Transpl 2018;24:946-60.

71. Guo W, Yang XR, Sun YF, Shen MN, Ma XL, et al. Clinical significance of EpCAM mRNA-positive circulating tumor cells in hepatocellular carcinoma by an optimized negative enrichment and qRT-PCR-based platform. Clin Cancer Res 2014;20:4794-805.

72. Kalinich M, Bhan I, Kwan TT, Miyamoto DT, Javaid S, et al. An RNA-based signature enables high specificity detection of circulating tumor cells in hepatocellular carcinoma. Proc Natl Acad Sci U S A 2017;114:1123-8.

73. Liu YK, Hu BS, Li ZL, He X, Li Y, et al. An improved strategy to detect the epithelial-mesenchymal transition process in circulating tumor cells in hepatocellular carcinoma patients. Hepatol Int 2016;10:640-6.

74. Wan S, Kim TH, Smith KJ, Delaney R, Park GS, et al. New labyrinth microfluidic device detects circulating tumor cells expressing cancer stem cell marker and circulating tumor microemboli in hepatocellular carcinoma. Sci Rep 2019;9:18575.

75. Hu B, Yang XR, Xu Y, Sun YF, Sun C, et al. Systemic immune-inflammation index predicts prognosis of patients after curative resection for hepatocellular carcinoma. Clin Cancer Res 2014;20:6212-22.

76. Wang BL, Tian L, Gao XH, Ma XL, Wu J, et al. Dynamic change of the systemic immune inflammation index predicts the prognosis of patients with hepatocellular carcinoma after curative resection. Clin Chem Lab Med 2016;54:1963-9.

77. Schulze K, Gasch C, Staufer K, Nashan B, Lohse AW, et al. Presence of EpCAM-positive circulating tumor cells as biomarker for systemic disease strongly correlates to survival in patients with hepatocellular carcinoma. Int J Cancer 2013;133:2165-71.

78. Kelley RK, Magbanua MJ, Butler TM, Collisson EA, Hwang J, et al. Circulating tumor cells in hepatocellular carcinoma: a pilot study of detection, enumeration, and next-generation sequencing in cases and controls. BMC Cancer 2015;15:206.

79. Yu JJ, Xiao W, Dong SL, Liang HF, Zhang ZW, et al. Effect of surgical liver resection on circulating tumor cells in patients with hepatocellular carcinoma. BMC Cancer 2018;18:835.

80. von Felden J, Schulze K, Krech T, Ewald F, Nashan B, et al. Circulating tumor cells as liquid biomarker for high HCC recurrence risk after curative liver resection. Oncotarget 2017;8:89978-87.

81. Shen J, Wang WS, Zhu XL, Ni CF. High epithelial cell adhesion molecule-positive circulating tumor cell count predicts poor survival of patients with unresectable hepatocellular carcinoma treated with transcatheter arterial chemoembolization. J Vasc Interv Radiol 2018;29:1678-84. 
82. Yao F, Guo JM, Xu CF, Lou YL, Xiao BX, et al. Detecting AFP mRNA in peripheral blood of the patients with hepatocellular carcinoma, liver cirrhosis and hepatitis. Clin Chim Acta 2005;361:119-27.

83. Zhou Y, Wang B, Wu J, Zhang C, Zhou Y, et al. Association of preoperative EpCAM circulating tumor cells and peripheral Treg cell levels with early recurrence of hepatocellular carcinoma following radical hepatic resection. BMC Cancer 2016;16:506.

84. Taketa K. Alpha-fetoprotein: reevaluation in hepatology. Hepatology 1990;12:1420-32.

85. Trevisani F, D’Intino PE, Morselli-Labate AM, Mazzella G, Accogli E, et al. Serum alpha-fetoprotein for diagnosis of hepatocellular carcinoma in patients with chronic liver disease: influence of HBsAg and anti-HCV status. J Hepatol 2001;34:570-5.

86. Fan ST, Yang ZF, Ho DW, Ng MN, Yu WC, et al. Prediction of posthepatectomy recurrence of hepatocellular carcinoma by circulating cancer stem cells: a prospective study. Ann Surg 2011;254:569-76.

87. Li YM, Xu SC, Li J, Han KQ, Pi HF, et al. Epithelial-mesenchymal transition markers expressed in circulating tumor cells in hepatocellular carcinoma patients with different stages of disease. Cell Death Dis 2013;4:e831.

88. Chen J, Cao SW, Cai Z, Zheng L, Wang Q. Epithelial-mesenchymal transition phenotypes of circulating tumor cells correlate with the clinical stages and cancer metastasis in hepatocellular carcinoma patients. Cancer Biomark 2017;20:487-98.

89. Ou H, Huang Y, Xiang L, Chen Z, Fang Y, et al. Circulating tumor cell phenotype indicates poor survival and recurrence after surgery for hepatocellular carcinoma. Dig Dis Sci 2018;63:2373-80.

90. Yin LC, Luo ZC, Gao YX, Li Y, Peng Q, et al. Twist expression in circulating hepatocellular carcinoma cells predicts metastasis and prognoses. Biomed Res Int 2018;2018:3789613.

91. Ye X, Li G, Han C, Han Q, Shang L, et al. Circulating tumor cells as a potential biomarker for postoperative clinical outcome in HBVrelated hepatocellular carcinoma. Cancer Manag Res 2018;10:5639-47.

92. Cheng Y, Luo L, Zhang J, Zhou M, Tang Y, et al. Diagnostic value of different phenotype circulating tumor cells in hepatocellular carcinoma. J Gastrointest Surg 2019;23:2354-61.

93. Wang Z, Luo L, Cheng Y, He G, Peng B, et al. Correlation between postoperative early recurrence of hepatocellular carcinoma and mesenchymal circulating tumor cells in peripheral blood. J Gastrointest Surg 2018;22:633-9.

94. Qi LN, Xiang BD, Wu FX, Ye JZ, Zhong JH, et al. Circulating tumor cells undergoing EMT provide a metric for diagnosis and prognosis of patients with hepatocellular carcinoma. Cancer Res 2018;78:4731-44.

95. Chen Y, Li S, Li W, Yang R, Zhang X, et al. Circulating tumor cells undergoing EMT are poorly correlated with clinical stages or predictive of recurrence in hepatocellular carcinoma. Sci Rep 2019;9:7084.

96. Wang S, Zheng Y, Liu J, Huo F, Zhou J. Analysis of circulating tumor cells in patients with hepatocellular carcinoma recurrence following liver transplantation. J Investig Med 2018;66:1-6.

97. Xue F, Shi S, Zhang Z, Xu C, Zheng J, et al. Application of a novel liquid biopsy in patients with hepatocellular carcinoma undergoing liver transplantation. Oncol Lett 2018;15:5481-8.

98. Qi LN, Ma L, Chen YY, Chen ZS, Zhong JH, et al. Outcomes of anatomical versus non-anatomical resection for hepatocellular carcinoma according to circulating tumour-cell status. Ann Med 2020;52:21-31.

99. Fan ZC, Yan J, Liu GD, Tan XY, Weng XF, et al. Real-time monitoring of rare circulating hepatocellular carcinoma cells in an orthotopic model by in vivo flow cytometry assesses resection on metastasis. Cancer Res 2012;72:2683-91.

100. Ha Y, Kim TH, Shim JE, Yoon S, Jun MJ, et al. Circulating tumor cells are associated with poor outcomes in early-stage hepatocellular carcinoma: a prospective study. Hepatol Int 2019;13:726-35.

101. Jin J, Niu X, Zou L, Li L, Li S, et al. AFP mRNA level in enriched circulating tumor cells from hepatocellular carcinoma patient blood samples is a pivotal predictive marker for metastasis. Cancer Lett 2016;378:33-7.

102. Wu X, Yang C, Yu H, Cao F, Shan Y, et al. The predictive values of serum dickkopf-1 and circulating tumor cells in evaluating the efficacy of transcatheter arterial chemoembolization treatment on hepatocellular carcinoma. Medicine (Baltimore) 2019;98:e16579.

103. Li Y, Huang N, Wang C, Ma H, Zhou M, et al. Impact of liver tumor percutaneous radiofrequency ablation on circulating tumor cells. Oncol Lett 2018;16:2839-50.

104. Rau KM, Liu CT, Hsiao YC, Hsiao KY, Wang TM, et al. Sequential circulating tumor cell counts in patients with locally advanced or metastatic hepatocellular carcinoma: monitoring the treatment response. J Clin Med 2020;9.

105. Tayoun T, Faugeroux V, Oulhen M, Aberlenc A, Pawlikowska P, et al. CTC-derived models: a window into the seeding capacity of circulating tumor cells (CTCs). Cells 2019;8.

106. Baccelli I, Schneeweiss A, Riethdorf S, Stenzinger A, Schillert A, et al. Identification of a population of blood circulating tumor cells from breast cancer patients that initiates metastasis in a xenograft assay. Nat Biotechnol 2013;31:539-44.

107. Yan J, Fan Z, Wu X, Xu M, Jiang J, et al. Circulating tumor cells are correlated with disease progression and treatment response in an orthotopic hepatocellular carcinoma model. Cytometry A 2015;87:1020-8.

108. Zhu L, Liu R, Zhang W, Qian S, Wang J. Application of EGFR inhibitor reduces circulating tumor cells during transcatheter arterial embolization. Clin Transl Oncol 2018;20:639-46.

109. Li J, Shi L, Zhang X, Sun B, Yang Y, et al. pERK/pAkt phenotyping in circulating tumor cells as a biomarker for sorafenib efficacy in patients with advanced hepatocellular carcinoma. Oncotarget 2016;7:2646-59.

110. Zhang Y, Zhang X, Zhang J, Sun B, Zheng L, et al. Microfluidic chip for isolation of viable circulating tumor cells of hepatocellular carcinoma for their culture and drug sensitivity assay. Cancer Biol Ther 2016;17:1177-87.

111. Aoki M, Shoji H, Kashiro A, Takeuchi K, Shimizu Y, et al. Prospects for comprehensive analyses of circulating tumor cells in tumor biology. Cancers (Basel) 2020;12.

112. D'Avola D, Villacorta-Martin C, Martins-Filho SN, Craig A, Labgaa I, et al. High-density single cell mRNA sequencing to characterize circulating tumor cells in hepatocellular carcinoma. Sci Rep 2018;8:1157. 